American Journal of Agricultural and Biological Sciences 7 (1): 71-75, 2012

ISSN 1557-4989

(C) 2012 Science Publications

\title{
Macroinvertebrate Communities Differences on Riverine Parts and Reservoirs of Zarrineh River
}

\author{
${ }^{1}$ Ahmadi, R., ${ }^{2}$ A. Aliyev, ${ }^{3}$ M. Seidgar, ${ }^{4}$ A. Bayramov and ${ }^{3}$ S. Ganji \\ ${ }^{1}$ Baku State University, \\ ${ }^{2}$ Inistitute of Zoology, Azerbaijan National Academy of Sciense, \\ Iranian Artemia Research Center (IFRO), Uremia, Iran \\ ${ }^{3}$ Iranian Artemia Research Center, Uremia, Iran \\ ${ }^{4}$ Inistitute of Naxjavan Bioresurces, Azerbaijan National Academy of Sciense
}

\begin{abstract}
This study was conducted to identify present macro invertebrate's fauna in reverine and reservoir parts of the Zarrinehrood River for fisheries purposes. The abundance and species composition of macro invertebrate were analyzed and compared in various parts of the Zarrinehrood River (west Azerbaijan, Iran) during November 2008-February 2009 to evaluate the rivers benthic fauna as a resource of fish and fowl feeding. Totally 67 macro invertebrate species were found in Zarrinehrood River. Concerning the macro invertebrate density, a high-density was detected on the summer thanks to the development of bacteria and moderate meta zooplanktons on the rivers bed. The density of Oligochaeta was higher on the polluted sites and dipper zone of the reservoirs but the population of chironomidae larvae increased on the heterotrophic shallow areas. Patchy distribution of Gastropod, Amphipod and Trichoptera occurred in the reverie stations with high water speed and dissolved oxygen. It was concluded that different environmental characteristics and eutrophication degrees of the sampled stations seem to be the main factors that determined the macro invertebrate's colonization and abundance. Therefore, preserving better trophy condition can guarantee biodiversity richness in various parts of the Zarrinehrood River.
\end{abstract}

Key words: Noruzloo and Bukan dams, zarrinehrood river, west azerbaijan, trophy condition, preserving better saproby, benthic macroinvertebrates, primary parts, stratification regime

\section{INTRODUCTION}

Within the aquatic communities, benthic macro invertebrates represent one of the groups most affected by dam construction (Krzyzanek and Kasza, 1995).

Different parts of a river varied in such influential characteristics that affects the structure of benthic communities such as, substrate type, stratification regime and dissolved oxygen dynamics on the reverine areas (Luis et al., 2007) and relative drainage basin size and water retention time on the reservoirs (Wetzel, 2001).

The water level of reservoirs is fluctuating and usually raised and lowered each year between the highest level in late spring and the lowest level in early fall. Seasonal drawdown, retention time, temperature and dissolved oxygen dynamics can affect the structure of the benthic community in the main body of the reservoir and its related surrounding lands (Furey et al., 2006).
Food availability and quantity, sediment type (organic, sandy, clay), substrate (rock, wood, aquatic macrophysics), water quality (temperature, oxygen and dissolved substances and turbidity affect community structure of macro invertebrates (Callisto et al., 2005) (Day et al., 2010).

These organisms represent an important relationship between primary producers, detritus deposits and higher tropic levels in aquatic food webs (Stoffels et al., 2005).

The formation of macro invertebrate communities depends on abiotic and biotic factors that vary across spatial scales from regional to habitat-specific and the external factors such as pollutants that influence the river and reservoirs (Lamouroux et al., 2004).

The goal of present study was to describe the benthic community from various parts of the Zarrinehrood River to explain the patterns of several environmental factors influence benthic macro invertebrate community structure and investigate how densities of several dominant taxa changes with respect to water flow rate and depth. 


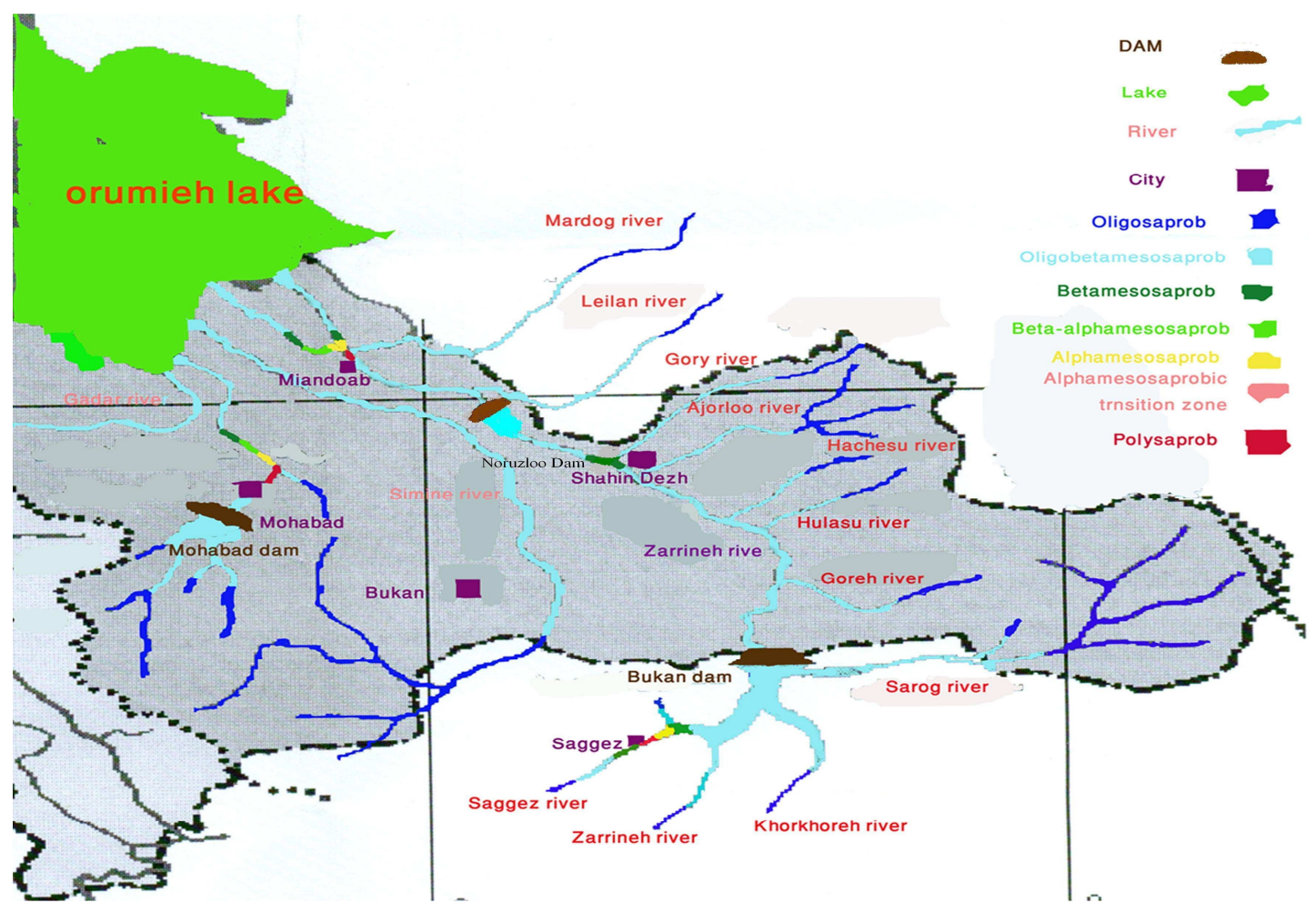

Fig. 1: Zarrinehrood River and the situation of its reservoirs

Table1: Macroinvertebrates identified manuals and identification keys that used in this study

\begin{tabular}{ll}
\hline Organisms groups & Identified manuals \\
\hline Oligochaeta & Pennak (1989) and Peckarsky (1990) \\
Hirudinea & Sladecek and Kosell (1984) \\
Mollusca (Gastropoda) & Zhadin (1952) \\
Amphipoda & Karaman (1977) \\
Decapoda & Hay (1896) and Hobbs (1989) \\
Odonata & CSIRO (1991) \\
Ephemeroptera & Elliott et al. (1988) \\
Hemiptera & Unwin (2001) \\
Trichoptera & Lawrence (1991) \\
Coleoptera & Skidmore (1991) \\
Diptera (Chironomidae) & Warwick (1990: Ashe, 1983) \\
\hline
\end{tabular}

\section{MATERIALS AND METHODS}

Site description: Zarrinehrood River is the most important fresh water source for Uremia Lake that represents over 49 percent of the freshwater input to the Lake in the northwest of Iran. Bukan and noruzloo dams have constructed in this river to control the water level, Bukan reservoir covers an area of about $42 \mathrm{~km}^{2}$ and has a mean volume of $762 \times 10^{6} \mathrm{~m}^{3}$. Maximum depth is 50 meters and its vertical fluctuation is around $25 \mathrm{~m}$ annually. The dam and its reservoir is located in a hilly region on the primary parts of the river but the noruzloo Reservoir $\left(36^{\circ} 52^{\prime} \mathrm{N}\right.$ and $\left.46^{\circ} 14^{\prime} \mathrm{E}\right)$ is located in the middle section of the zarrineh River, in the west side of Miandoab city (Fig. 1). The reservoir covers an area of about $10 \mathrm{~km}^{2}$ and has a mean volume of $25 \times 10^{6} \mathrm{~m}^{3}$. Maximum depth is 6 meters. Its surroundings are characterized by pasture and agricultural areas. The climate in the region is classified as exothermal, with dry summers and rainy winters.

Totally, 25 sites were sampled from its headspring parts to its estuary parts near Urmia Lake with $14 \mathrm{~km}$ distance across the river. Three replicate samples from each site and its suburbs were collected. Samples were placed in plastic jars with labels and preserved in alcohol.. Processing of the samples was conducted from November 2008-2009.

Samples were washed with tap water on a $500 \mu \mathrm{m}-$ mesh brass sieve to remove the alcohol and finer debris. The remaining material was placed in a white enamel pan for separating animals from the larger debris. If a sample contained relatively few animals $(<100)$, all animals were collected. If a sample contained a large number of animals, all of the uncommon taxa was collected completely and abundant taxa (typically Chironomidae) were subsampled (Galbrand et al., 2007). Identifications were based on keys given in the taxonomic References, indicated on Table 1. 
Am. J. Agri. \& Biol. Sci., 7 (1): 71-75, 2012

Most animals were intact and identifiable from the field samples, but a few taxa showed evidence of significant decomposition during 1-year period between collection and processing. Snails were often present only as empty shells and oligochaetes frequently disintegrated during washing. Statistical tests (e.g., descriptive measures, regression and correlation, comparisons of means between samples, principal components analysis) were calculated using SPSS analytical Software.

\section{RESULTS AND DISCUSSION}

Macro invertebrate taxa collected from various parts of Zarrineh River showed on Table 2. Since macro invertebrates vary in their habitat and environmental requirements and preferences, it is likely to find spatial differences in terms of macro invertebrate's community make up and abundances. This is predictable because the Zarrinehrood River through its direction gradient provides a wide range of habitats and environmental conditions.

The results indicated that greater densities of oligochaetes, including both Limnodrilus and Branchiura and the fingernail clam, Pisidium, were found in association with areas of greater sediment organic matter including the area deeper than $(5-8 \mathrm{~m})$ both on the bukan and norouzloo reservoirs.

On the Bukan reservoir that contains more deep areas, the oligochaeta were the richest group with greater densities but on the norouzloo reservoir with more shallow areas, Chironomidae were the richest group and found in greater densities.

Higher Larval densities of Ceratopogonidae and Chaoborus punctipennis were observed with increasing depth on the bukan reservoire but they had larger densities on norouzloo reservoire due to its faunal richness.

On the sampling sites that situated across the riverine sections, the richest taxons belong to Gastropod, Amphipod and Trichoptera. On the reverine stations with more water movement, taxons like Limnaea truncatula, Gammarus komareki and Limnophilus clavicornis found in greater densities. Macro invertebrates biomass varied on the sampling sites, fluctuated seasonally but the greater biomass of total taxa found on summer. Also among different parts of the river, Norouzloo reservoire with the mean amount of more than $5.4 \mathrm{~g} \mathrm{~m}^{-2}$. The bukan reservoire with $3.6 \mathrm{~g} \mathrm{~m}^{-2}$ and riverine sites with $2.6 \mathrm{~g} \mathrm{~m}^{-2}$ had less total biomass, respectively.

The mean density of macro invertebrates were 958 ind. $\mathrm{m}^{-2}$ with a range of $0-4000$ ind. $\mathrm{m}^{-2}$. Distribution pattern was patchy (standard deviation was 574 macro invertebrates ind. $\mathrm{m}^{-2}$ ).
Table 2: Macroinvertebrate taxa collected from various parts of zarrineh river

\begin{tabular}{llll}
\hline Genus/specie & $\begin{array}{l}\text { Riverine } \\
\text { sites }\end{array}$ & $\begin{array}{l}\text { Noruzloo } \\
\text { reservoir }\end{array}$ & Bukan \\
reservoir
\end{tabular}

\section{Oligochaeta}

Peloscolex ferox (Eisen, 1879)

Limnodrilus udekemianus(Clapare`de,1862)

Limnodrilus hoffmeisteri (Claparède, 1862)

Branchiura sowerbyi (Beddard, 1892)

Stylaria lacustris (Linnaeus, 1767)

Aulodrilus pigueti (Kowalewski, 1914)

Tubifex tubifex (Mueller, 1774)

lumbriculus variegatus (Mueller, 1774)

Rhyacodrilus coccineus (Vejdovsky, 1875)

Aulophorus furcatus (Müller, 1773)

Hirudinea

Helobdella stagnalis (Linnaeus, 1758)

Piscicola geometra (Linnaeus, 1761)

Gloiobdella obscura (Ringuelet, 1942)

Barbronia weberi (Blanchard, 1897)

Erpobdella octoculata (Linnaeus, 1758)

Gastropoda

Lymnaea stagnalis (Linnaeus, 1758)

Valvata cristata (Müller, 1774)

Viviparus viviparus (LINNAEUS 1758)

Limnaea truncatula (Müller, 1774)

Lymnaea auricularia (Linnaeus, 1758 ,

Costatella acuta (Draparnaud, 1805)

Melanopsis tuberculata (Muller, 1774)

Bivalves

Sphaerium corneum (Linnaeus, 1758)

Dreissena polymorpha (Pallas 1771)

Pisidium amnicum (Muller, 1774)

Sphaerium rivicola (Lamarck, 1818)

Amphipoda

Pontogammarus sarsi (Sowinsky, 1898)

Asellus aquaticus (Linnaeus, 1758)

Rivulogammarus pulex (Linnaeus, 1758)

Gammarus komareki (Schäferna, 1922)

Decapoda

Potamon bericum bieb(olev.)

Palaemon elegans (Rathke, 1837)

Odonata

Agrion splendens (Harris, 1776)

Gomphus vulgatissimus (Linnaeus, 1758)

Coenagrion mercuriale (Charpentier, 1840 )

Coenagrion hastulatum (Charpentier, 1825 )

Ephemeroptera

Ephemerella ignita (Poda, 1761)

Ephemera danica (Muller, 1764)

Cloeon simile (Eaton, 1870)

Campusurus notatus (Eaton, 1868)

Baetis rhodani (Pictet, 1843)

Plecoptera

Amphinemura sulicicollis (Stephens, 1836)

İsoperla grammatica (Poda, 1761)

Hemiptera

Ranatra linearis (Linnaeus, 1758)

Sigara dorsalis (Leach, 1817)

Nepa cinerea (Linnaeus, 1758)

Trichoptera

Limnephilus lunatus (Curtis, 1834)

Limnophilus flavicornis (Fabricius, 1787)

Coleoptera

Haliplus fluviatilis (Aubé, 1836)

Elmis maugei (Bedel, 1878)

Laccophillus hyalinus (De Geer, 1774)

Diptera: Chaoboridae

Chaoborus crystallinus (De Geer, 1776)

Chaoborus punctipennis (Say, 1823)

Ceratopogonidae

Culicoides impunctatus (Goetghebuer 1920)

Chironomidae

Coelotanypus tricolor (Loew, 1861)

Tanytarsus gregarius (Kieffer, 1909)

Tanytarsus lauterborni (Kieffer, 1909)

Tanytarsus exiguus (Johannsen, 1905)

Cryptochironomus camptolabis (Kieffer

Cryptochironomus defectus (Kieffer, 1913)

Microchironomus nigrovittatus(Malloch, 1915) +

Cricotopus biformis (Edwards, 1929)

Microtendipes chloris (Meigen, 1818)

Chironomus plumosus (Linnaeus, 1758)

Chironomus plumosus (Linnaeus, 1758 )
Goeldichironomus pictus (Reiss, 1974)

Goeldichironomus pictus (Reiss,
Procladius choreus (Meigen, 1804)

Tanypus stellatus (Coquillett, 1902) sites reservoir reservoir

\begin{tabular}{|c|c|c|}
\hline - & + & + \\
\hline+ & + & - \\
\hline - & + & + \\
\hline - & + & + \\
\hline+ & + & - \\
\hline - & + & - \\
\hline+ & - & - \\
\hline+ & - & - \\
\hline+ & - & - \\
\hline+ & - & - \\
\hline+ & + & + \\
\hline+ & + & + \\
\hline - & + & + \\
\hline - & + & + \\
\hline+ & - & - \\
\hline - & + & - \\
\hline+ & - & - \\
\hline+ & - & - \\
\hline+ & - & - \\
\hline+ & + & - \\
\hline+ & + & \\
\hline - & - & + \\
\hline+ & + & + \\
\hline+ & - & - \\
\hline+ & - & - \\
\hline+ & - & - \\
\hline - & + & - \\
\hline+ & - & - \\
\hline+ & - & - \\
\hline+ & + & + \\
\hline - & - & + \\
\hline+ & + & - \\
\hline+ & - & - \\
\hline+ & - & - \\
\hline+ & - & - \\
\hline - & + & + \\
\hline - & + & + \\
\hline+ & - & - \\
\hline+ & - & - \\
\hline - & + & + \\
\hline+ & + & + \\
\hline+ & - & - \\
\hline+ & - & - \\
\hline+ & - & - \\
\hline t- & - & - \\
\hline+ & + & + \\
\hline+ & - & - \\
\hline+ & + & + \\
\hline+ & - & - \\
\hline+ & - & - \\
\hline+ & + & + \\
\hline+ & + & + \\
\hline+ & + & - \\
\hline+ & + & + \\
\hline+ & + & - \\
\hline+ & + & - \\
\hline - & + & - \\
\hline - & + & + \\
\hline - & - & + \\
\hline+ & + & - \\
\hline+ & + & - \\
\hline - & + & - \\
\hline - & + & - \\
\hline+ & + & + \\
\hline+ & + & + \\
\hline+ & + & + \\
\hline+ & + & + \\
\hline
\end{tabular}


Few macro invertebrates were collected from polluted riverine sites and deepest zone on bukan reservoir. Also with few exceptions (i.e., some taxa of odonata) the only invertebrates collected from such clean rocky habitats on the reverine sites were Chironomus larvae and Ephemera.

\section{CONCLUSION}

The species composition of the zarrinehrood river macro benthos was not greatly different from that of observed on its surrounding wetlands (Ahmadi et al., 2011) and several other local rivers, including Aras river and its reservoir (Aliyev and Ahmadi 2010). Oligochaeta live in organic and sandy environments (Brinkhurst and Jamieson, 1971). They are able to survive for prolonged periods of anoxia (Lang, 1997), high organic loadings (Milbrink, 1994) and positively correlate with the eutrophication degree (Yisa and Jimoh, 2010) and strongly influence by organic matter deposition patterns (Ramsey and David, 2007). They were the dominant taxa both on the deepest zone of bukan reservoir and in a much polluted shallow areas on the riverine zone. But in noruzloo reservoir. The dominance of the chironomus was due to the preference of these organisms to feeding the free floating vegetation and deposite plants. They could provide flexible habitats, wide food resources, breeding places and refugia against predators to the chironomidae larvae (Luis et al., 2007). It was reported that shallow reservoirs like this could provide diversified habitats to many of chironomidae and other macrobentoses because the higher richness and densities of macro benthic fauna in places rich in aquatic vegetation (Salman et al., 2009). Chironomidae may also inhabit in great variety of places but are characteristic to dammed environments (Growns and Growns, 2001). Larvae are r-strategists (Bhattacharya and Chattopadhyay, 2010) and adapt themselves to several different environments. Such adaptability favors the presence and abundance of these invertebrates in the reservoir. On the other hand, high concentrations of dissolved oxygen and water speed, coupled to sediment formed by sand, were the main factors affecting high density and diversity of_Gastropod, Amphipod and Trichoptera in the riverine sites. Different environmental characteristics and eutrophication degree of the sampled sites seem to be the main factors that determine the invertebrate's colonization and abundance in the Zarrinehrood River. It is recommended that the good management and preserving better trophy condition can guarantee biodiversity richness in various parts of the Zarrinehrood river.

\section{REFERENCES}

Ahmadi, R., F. Mohebbi, P. Hagigi, L. Esmailly and R. Salmanzadeh, 2011., Macro-invertebrates in the Wetlands of the Zarrineh estuary at the south of Urmia Lake (Iran) Int. J. Environ. Res., 5: 10471052.

Aliyev, A. and R. Ahmadi, 2010. Biodiversity of benetic invertebrates in aras river. Iranian Sci. Fisheries J. Persian, 19: 2-2.

Ashe, P., 1983. A catalogue of chironomid genera and subgenera of the world including synonyms (Diptera: Chironomidae). 1st Edn., Scandinavian Society of Entomology, Sweden, pp: 68.

Bhattacharya, J.P.S. and J. Chattopadhyay, 2010. Does predator go for size selection or preferential toxicnontoxic species under limited resource? OnLine J. Biol. Sci., 10: 11-16. DOI: 10.3844/ojbsci.2010.11.16

Brinkhurst, R.O. and B.M.G. Jamieson, 1971. Aquatic Oligochaeta of the world. 1st Edn., University of Toronto Press, Toronto, ISBN-10: 0802018335, pp: 860.

Callisto, M., M. Goulart, F.A.R. Barbosa and O. Rocha, 2005. Biodiversity assessment of benthic macroinvertebrates along a reservoir cascade in the lower Sao Francisco river (northeastern Brazil). Braz. J. Biol., 65: 1-6. DOI: 10.1590/S151969842005000200006

CSIRO, 1991. The Insects of Australia: A Textbook for Students and Research Workers. 2nd Edn., Cornell University Press, ISBN: 0801426707, pp: $1137 .$.

Day, J., 2010. The Assessment of Temporary Wetlands During Dry Conditions. 1st Edn., Water Research Commission, Gezina, South Africa, ISBN: 1770059261, pp: 129.

Elliott, J.M., U.H. Humpesch and T.T. Mecan, 1988. Larvae of the british ephemeroptera: A key with ecological notes. J. North Am. Benthol. Soc., 49: 145-145.

Furey, P.C., R.N. Nordin and A. Mazumder, 2006. Littoral benthic macroinvertebrates under contrasting drawdown in a reservoir and a natural lake. J. North Am. Benthol. Soc., 25: 19-31.

Galbrand, C. , Lemieux, I. G., Ghaly A. E., Côté R. and M. Verma, 2007. Assessment of Constructed Wetland Biological Integrity Using Aquatic Macroinvertebrates. OnLine J. Biol. Sci.,7: 52-65. DOI: $10.3844 /$ ojbsci.2007.52.65

Growns, I.O. and J.E. Growns, 2001. Ecological effects of flow regulation on macroinvertebrate and periphytic diatom assemblages in the HawkesburyNepean River, Australia. Regul. Rivers Res. Manag., Chichester, 17: 275-293. DOI: $10.1002 /$ rrr.622 
Hay, W.P., 1986. The Crawfishes of the state of Indiana. 20th Annual Report of the Department of Geology and Natural Resources of Indiana.

Hobbs, H.H.J., 1989. An illustrated checklist of the american crayfishes (decapoda, astacidae, cambaridae, parastacidae). Smithsonian Contributions Zool., 480: 1-236. DOI: 10.1002/ajpa.1330600419

Karaman, G.S., 1977. Freshwater Gammarus species from Europe, North Africa and adjacent regions of Asia (Crustacea-Amphipoda). III: Gammarus balcanicus-group and related species. Bijdragen tot de dierkunde, 57: 207-260.

Krzyzanek, E. and H. Kasza, 1995. Formation of bottom macrofauna in the Goczalkowice Reservoir (southern Poland) against the background of changing selected physico-chemical properties of the water. Krakowl. Acta Hydrobiol., 37: 103-111.

Lamouroux, N., S. Doledec and S. Gayraud, 2004. Biological traits of stream macroinvertebrate communities: Effects of microhabitat, reach and basin filters. J. North Am. Benthol. Soc., 23: 449466.

Lang, C., 1997. Oligochaetes, organic sedimentation, and trophic state: how to assess the biological recovery of sediments in lakes? Aquat. Sci., 59: 2633. DOI: 10.1007/BF02522547

Lawrence, J.F., 1991. The Insects of Australia 2. 2nd Edn., Cornell Univ. Press, Ithaca, N.Y., ISBN-10: 0801426693, pp: 1137.

Luis, R., M. Cordova, and F. Luis and E. Ocana, 2007. Study of benthic fauna in the discharge lagoon of a shrimp farm with special emphasis on the polychaetes. OnLine J. Biol. Sci., 12-17. DOI: 10.3844/ojbsci.2007.12.17

Milbrink, G., 1994. Oligochaetes and water pollution in two deep Norwegian lakes. Hydrobiologia, 278: 213-222. DOI: 10.1007/BF00142329

Peckarsky, B.L., 1990. Freshwater Macroinvertebrates of Northeastern North America. 1st Edn., Comstock Pub. Associates, Ithaca, ISBN-10: 0801420768 pp: 442.

Pennak, R.W., 1989. Fresh-water Invertebrates of the United States. 3rd Edn., Wiley, New York, ISBN10: 0471631183 pp: 628.
Ramsey, J.B. and W. David, 2007. Spatial distribution of benthic macroinvertebrates in a sidearm embayment of kentucky lake. Science, 68: 50-58.

Salman,I. A. Al-hami, M.N.S. Azizah, Che S.M. Rawi and A.H. Ahmad, 2009. preliminary study of phylogenetic relationship of rice field chironomidae (Diptera) inferred from DNA sequences of mitochondrial cytochrome oxidase subunit. Am. J. Applied Sci., 6: 1004-1009. DOI: 10.3844/ajassp.2009.1004.1009

Skidmore, P., 1991. Insects of the British Cow-Dung Community. 1st Edn., Field Studies Council, ISBN-10: 1851538216, pp: 166.

Sladecek, V. and V. Kosell, 1984. Indicator value of freshwater leeches (hirudinea) with a key to the determination of european species. hydrochimica et hydrobiologica, 12: 451-461. DOI: 10.1002/aheh.19840120502

Stoffels, R.J., K.R. Clarke and G.P. Closs, 2005. Spatial scale and benthic community organisation in the littoral zones of large oligotrophic lakes: potential for cross-scale interactions. Freshwater Biol., 50: 1131-1145. DOI: 10.1111/j.13652427.2005.01384.x

Unwin, D.M., 2001. A Key to the Families of British Bugs (Insecta, Hemiptera). 1st Edn., Field Studies Council, Shrewsbury, ISBN-10: 1851532129, pp: 35.

Warwick, W.F., 1990. Morphological deformities in chironomidae (Diptera) larvae from the Lac St. louis and laprairie basins of the st. lawrence river. J. Great Lakes Res., 16: 185-208. DOI: 10.1016/S0380-1330(90)71413-X

Wetzel, R.G., 2001. Limnology: Lake and River Ecosystems. 3rd Ed., Academic Press, San Diego, ISBN-10: 0127447601, pp: 1006.

Yisa, J. and T. Jimoh, 2010. Analytical studies on water quality index of river landzu. Am. J. Applied Sci., 7: 453-458. 10.3844/ajassp.2010.453.458

Zhadin, V., 1952. Ussr fresh and brakish-water Molluses. USSR Acadmic Science, Leningrad. 